\title{
BRCA1 mutations in Brazilian patients
}

Juliano Javert Lourenço ${ }^{1,2}$, Fernando R. Vargas ${ }^{1,3}$, José Bines ${ }^{4}$, Elizete M. Santos ${ }^{6}$, Cezar A.P. Lasmar ${ }^{6}$, Célia H. Costa ${ }^{4}$, Eliane M.B. Teixeira ${ }^{6}$, Maria C.M. Maia ${ }^{4}$, Fátima Coura ${ }^{4}$, Carlos H.D. Silva ${ }^{5}$ and Miguel A.M. Moreira ${ }^{1}$

${ }^{1}$ Instituto Nacional de Câncer, Coordenação de Pesquisa, Divisão de Genética, Rio de Janeiro, RJ, Brazil.

${ }^{2}$ Universidade Federal do Rio de Janeiro, Departamento de Genética, Rio de Janeiro, RJ, Brazil.

${ }^{3}$ Universidade do Rio de Janeiro, Departamento de Genética, Rio de Janeiro, RJ, Brazil.

${ }^{4}$ Instituto Nacional de Câncer, HCI, Rio de Janeiro, RJ, Brazil.

${ }^{5}$ Instituto Nacional de Câncer, HCII, Rio de Janeiro, RJ, Brazil.

${ }^{6}$ Instituto Nacional de Câncer, HCIII, Rio de Janeiro, RJ, Brazil.

\begin{abstract}
BRCA1 mutations are known to be responsible for the majority of hereditary breast and ovarian cancers in women with early onset and a family history of the disease. In this paper we present a mutational survey conducted in 47 Brazilian patients with breast/ovarian cancer, selected based on age at diagnosis, family history, tumor laterality, and presence of breast cancer in male patients. All 22 coding exons and intron-exon junctions were sequenced. Constitutional mutations were found in seven families, consisting of one insertion (insC5382) in exon 20 (four patients), one four base-pair deletion (3450-3453delCAAG) in exon 11 resulting in a premature stop codon (one patient), one transition (IVS17+2T > C) in intron 17 affecting a mRNA splicing site (one patient), and a C $>\mathrm{T}$ transition resulting in a stop-codon (Q1135X) in exon 11 (one patient). The identification of these mutations which are associated to hereditary breast and ovarian cancers will contribute to the characterization of the mutational spectrum of $B R C A 1$ and to the improvement of genetic counseling for familial breast/ovarian cancer patients in Brazil.
\end{abstract}

Key words: BRCA1, breast cancer, ovarian cancer.

Received: November 19, 2003; Accepted: April 16, 2004.

The Breast Cancer Linkage Consortium dataset indicates that the proportion of familial breast and ovarian cancers associated to $B R C A 1$ or $B R C A 2$ may be as high as $98 \%$ (Martin et al., 2001). Mutations in BRCA1 account for $45 \%$ of families with multiple cases of breast cancer and for at least $80 \%$ of families with early-onset breast and/or ovarian cancer (Miki et al., 1994). Moreover, $88 \%$ of families with at least four cases of early-onset breast cancer and one case of ovarian cancer are related to mutations in $B R C A 1$ and $B R C A 2$ (Unger et al., 2000). Furthermore, germ line $B R C A 1$ or $B R C A 2$ mutation carriers also have an increased risk of developing other cancers in prostate, stomach, colon, pancreas, fallopian tubes and uterus when compared to the general population (Offit, 1998; Brose et al., 2002). However, the alternative possibility of mutations in other, still unidentified susceptibility genes with low penetrance or chance clustering in families with multiple cases of

Send correspondence to M.A.M. Moreira. Divisão de Genética, Coordenação de Pesquisa, Rua André Cavalcanti 37, $4^{\circ}$ andar, 20231-050 Rio de Janeiro, RJ, Brazil. E-mail: miguelm@inca. gov.br. breast/ovarian cancer without mutations in $B R C A 1$ or $B R C A 2$ remains to be determined.

More than 800 different mutations were reported in $B R C A 1$, and most of them are listed in the Breast Cancer Information Core (BIC - http://research.nhgri.nih.gov/bic/). Mutation carriers have an increased risk of developing breast cancer at different ages, with estimates of approximately $37 \%$ up to 40 years, $66 \%$ up to $55,73 \%$ up to 70 , and $82 \%$ over their entire lifetime (Hall et al., 1990; Brose et al., 2002). As for ovarian cancer, the risk was estimated to be $29 \%$ up to 50 years and $40 \%$ up to 70 years (Ford et al., 1998; Kasprazak et al., 1999; Brose et al., 2002).

Mutation detection and estimates of prevalence, however, are restricted to North America and Europe (Los Rios et al., 2001, Loman et al., 2001, Brose et al., 2002), while data from other populations are scarce. For instance, most studies carried out in individuals of African origin are restricted to African Americans (Olopade et al. 2003; Kinney et al., 2001; Shen et al., 2000; Gao et al., 2000). Altogether, studies in Latin American populations are so far restricted to a few reports: (i) mutational data and description of rare 
variants of unknown significance in $B R C A 1$ and $B R C A 2$ in Mexico (Ruiz-Flores et al., 2002); (ii) a study of an Uruguayan population describing six different mutations, five in BRCA2 and one in BRCA1 (Delgado et al., 2003); (iii) a study of 64 Brazilian patients (Simon et al., 2003) with a family history of breast and/or ovarian cancer, with 17 detected variants including the classical Askhenazi Jewish mutations (185-186delAG and 5382insC in BRCA1, and 6174delT in BRCA2); (iv) another Brazilian study describing a nonsense mutation and a missense mutation of unknown value (Corvello et al., 1998); and (v) two Chilean studies (Trincado et al., 1999; Jara et al., 2002) testing women (with a family history of breast cancer) for the mutations 185-186delAG, 5382incC and 6174delT (in $B R C A 2)$, which did not find these mutations in the sampled individuals.

In Brazil, mutational surveys of $B R C A 1 / B R C A 2$ are needed for determining which mutations are relevant for the prevalence of hereditary breast/ovarian cancer, in view of the multi-ethnic composition of the population (AlvesSilva et al., 2000, Carvalho-Silva et al., 2001). The investigation of this multi-ethnic population might lead to the discovery of new pathologic variants, resulting in a different mutational profile from those of European and North American populations.

Here we present the results of a mutational survey carried out in 47 Brazilian patients with breast/ovarian cancer, selected according to several inclusion criteria for high-risk inherited susceptibility. This survey, restricted to $B R C A 1$, was based on DNA sequencing of coding and intron/exon flanking regions.

\section{Patients}

Forty-seven unrelated patients were selected according to criteria based on a number of previous reports (Friedman et al., 1994; Langston et al., 1996; Hamann et al., 1997; Ford et al., 1998), listed in Table 1. All selected patients and their tested relatives signed informed consent forms guaranteeing privacy. Five milliliters of peripheral blood were collected for genomic DNA isolation, as described by Miller et al. (1988). All patients were unrelated. The mean age for first breast tumor diagnosis was 46 years, ranging from 23 to 76 , and for the second breast tumor it was 47.1 years, ranging from 38 to 61 . For ovarian cancer, the mean age of diagnosis was 36 years, ranging from 20 to 43. Two patients were of Ashkenazi Jewish origin, four patients were of European origin, one of them with a Ukrainian and an Italian parent, two patients of Italian origin (one of them being Italian), and one patient with a German and a Portuguese parent. The other 38 patients were from the local Brazilian population of multi-ethnic origin.

\section{Exon amplification and DNA sequencing}

The 22 BRCAl coding exons and flanking intronexon regions were PCR-amplified with 27 primer pairs.
Table 1 - Number of patients included in each selection criterion. A total of 47 unrelated patients were selected, with some of them fitting more than one criterion ${ }^{1}$.

\begin{tabular}{lc}
\hline Criterion of inclusion & Patients \\
\hline $\begin{array}{l}\text { I. Breast cancer patient with family history of breast cancer } \\
\text { and one or more cases of ovarian cancer at any age }\end{array}$ & 2 \\
$\begin{array}{l}\text { II. Breast cancer patient diagnosed before age 50, with } \\
\text { family having more than three cases of breast cancer diag- } \\
\text { nosed before age 50 }\end{array}$ & 8 \\
$\begin{array}{l}\text { III. Breast cancer patient and a first-degree relative with } \\
\text { breast and/or ovarian cancer diagnosed before age 50 }\end{array}$ & 27 \\
$\begin{array}{l}\text { IV. Male patient with breast cancer diagnosed at any age } \\
\text { V. Patient with bilateral breast or ovarian cancer diagnosed }\end{array}$ & 13 \\
before age 50 & 4 \\
VI. Ashkenazi Jewish patient with breast or ovarian cancer \\
at any age
\end{tabular}

${ }^{1}$ Some patients fitted more than one criterion: one patient fitted I and V; one fitted I, II and III; one 5382insC mutation carrier fitted III and V; two patients fitted II and III; and two carriers of different mutations (5382insC and 3450-3453delCAAG) fitted II, III, and V.

Most primer sequences were described by Miki et al., (1994). In view of its large size, exon 11 was amplified in seven overlapping fragments (named $11 \mathrm{~A}$ to $11 \mathrm{G}$ ), using the following primer pairs:

11A-f GGAATTAAATGAAAGAGTATGAGC/11 A-r TGTGAGGGGACGCTCTTG; 11B-f TTGGGAAAA CCTATCGGAA/ 11B-r ATCTTTGGGGTCTTCAGCA; 11C-f GTGTTCAAATACCAGTGAACTTA/ 11C-r GG AGCCCACTTCATTAGTAC; 11D-f CCAAGTACAGT GAGCACAATTA/ 11D-r GTGCTCCCAAAAGCATAA A; 11E-fCAGGAAATGCAGAAGAGGAATGTG/ 11E-r GAGCCCACTTCATTAGTAC; 11F-f CCAAGTACAG TGAGCACAATTA/ 11F-r GTGTTGGAAGCAGGGAA GCTCTTC; and 11G-f GAAGAGCTTCCCTGCTTCCA ACAC/ 11G-r GTGCTCCCAAAAGCAT AAA ( $\mathrm{f}=$ forward primer; $\mathrm{r}=$ reverse primer). $\mathrm{PCR}$ amplifications were carried out in a final volume of $50 \mu \mathrm{L}$ containing: $50 \mathrm{mM}$ Tris pH 9.0, $1.5 \mathrm{mM} \mathrm{MgCl}_{2}, 40 \mathrm{mM} \mathrm{KCl,} 250 \mu \mathrm{M}$ of each dNTP, 50 pmol of each primer and $1 \mathrm{U}$ of Taq DNA polymerase and 100-200 ng of genomic DNA. Amplification cycles were: $94^{\circ} \mathrm{C}$ for 5 min followed by 35 cycles of $94^{\circ} \mathrm{C}$ for $1 \mathrm{~min}, 55^{\circ} \mathrm{C}$ for $1 \mathrm{~min}$, and $72^{\circ} \mathrm{C}$ for $1 \mathrm{~min}$, except for exon 2 and $20\left(94^{\circ} \mathrm{C}\right.$ for 4 min followed by 35 cycles of $94^{\circ} \mathrm{C}$ for $45 \mathrm{~s}, 60^{\circ} \mathrm{C}$ for $30 \mathrm{~s}$, and $72{ }^{\circ} \mathrm{C}$ for $30 \mathrm{~s}$ ), exon 8 $\left(94{ }^{\circ} \mathrm{C}\right.$ for $5 \mathrm{~min}$, followed by 35 cycles of $94^{\circ} \mathrm{C}$ for $45 \mathrm{~s}$, $47^{\circ} \mathrm{C}$ for $30 \mathrm{~s}$, and $72^{\circ} \mathrm{C}$ for $30 \mathrm{~s}$ ), and the fragment $11 \mathrm{G}$ of exon $11\left(94{ }^{\circ} \mathrm{C}\right.$ for $5 \mathrm{~min}$, followed by 40 cycles of $94{ }^{\circ} \mathrm{C}$ for $1 \mathrm{~min}, 65^{\circ} \mathrm{C}$ for $1 \mathrm{~min}$, and $72^{\circ} \mathrm{C}$ for $1 \mathrm{~min}$ ). Amplification products were purified with $\mathrm{GFX}^{\mathrm{TM}} \mathrm{PCR}$ DNA and Gel Band Purification Kit (Amersham Biosciences) or Wizard PCR Preps DNA Purification System Kit (Promega), according to the manufacturer's guidelines. Subsequently, purified PCR products were sequenced in both forward and reverse directions, using the DYEnamyc ${ }^{\mathrm{TM}}$ ET Terminator 
Cycle Sequencing Premix Kit or the DYEnamic ET Dye Terminator Cycle Sequencing Kit for Megabace (both from Amersham Biosciences). Sequencing reactions were run in an ABI Prism 377 DNA Sequencer (Applied Biosystems) or in a MegaBACE 1000 DNA Sequencer (Amersham Biosciences). Sequence analyses were performed with the software Sequence Analysis version 3.3 (for ABI-Prism 377) or Sequence Analysis version 2.1 (for Megabace 1000). All mutations were observed in both strands and confirmed by another PCR reaction with material from the same patient.

Twenty seven patients (48\%) fulfilled criterion III (proband with one first-degree relative with breast and/or ovarian cancer diagnosed before age 50), 13 patients $(23 \%)$, criterion $\mathrm{V}$ (proband with bilateral breast or ovarian cancer diagnosed before age 50), eight patients (14\%), criterion II, four patients (7\%), criterion IV (one of them with two relatives with breast cancer, and another with a relative with bilateral breast cancer diagnosed at 36 and 50 years, respectively), two Ashkenazi Jewish patients (4\%) followed criterion VI, and two other patients (4\%), criterion I. Some patients fitted more than one criterion: one patient met criteria I and V; one, criteria I, II and III; one mutation carrier of 5382insC fulfilled criteria III and V; two patients, criteria II and III; and two carriers of different mutations (5382insC and 3450-3453delCAAG) fitted criteria II, III, and $\mathrm{V}$ (Table 1).

The average age at diagnosis was 41.6 years, ranging from 25 to 48 for first tumor diagnosis. Only one patient with bilateral tumors had the second tumor diagnosed after age 50, while the other two patients with bilateral tumors had their first tumor diagnosed at 33 and 47 years, and the second tumor at 38 and 50 years, respectively.

Tumor-associated mutations were found in seven (15\%) of the 47 patients (Table 2). They comprised: (i) an identical insertion (5382insC) in exon 20 in four patients; (ii) a four base-pair deletion (3450-3453delCAAG) in exon 11 resulting in an early stop codon in one patient; (iii) a transition (IVS17+2T $>\mathrm{C}$ ) in intron 17 affecting a mRNA splicing site in one patient; and (iv) a $\mathrm{C}>\mathrm{T}$ transition $(\mathrm{Q} 1135 \mathrm{X})$ in exon 11 resulting in a stop-codon in another patient. All these mutations were present in heterozygosis and, to our knowledge, the carriers came from unrelated families.

The frequency of BRCA1 mutations detected in our sample (15\%) was similar to those reported previously using similar inclusion criteria and mutation detection methodologies (Frank et al., 1998; Durocher et al. 1996). However, in studies using more stringent inclusion criteria for a hereditary profile (like families with three cases of breast cancer at a young age or two cases of breast cancer and one case of ovarian cancer, both diagnosed at a young age), mutations were detected in $40 \%$ of patients (Simard $e t$ al., 1994). Conversely, the proportion of detected tumorassociated mutations was lower (12.8\%) with less stringent criteria (Shattuck-Eidens et al., 1997).

Despite being the best methodological procedures for mutation detection, PCR amplification and DNA sequencing failed to detect an important proportion of mutations (around 10-15\%) like deletions, duplications and inversions encompassing large genome segments (Rohlfs et al., 2000; Unger et al. 2000, Brown et al., 2002, Montagna et $a l ., 2003)$. Therefore, patients with a strong familiar history but without detectable mutations in coding exons or intron-exon junction should not be excluded as potential mutation carriers. Detection must be based on other methodologies, like Southern blotting or long-distance PCR assays.

The relevance of a mutation can be evaluated by its frequency and penetrance in different human populations. Four of our patients, with bilateral ovarian or breast cancer (Table 1), carried a 5382insC, first described by Simard et al. (1994) and found to be very frequent in Ashkenazi Jews (0.13\%; see Abeliovich et al., 1997), East-European populations (Szabo and King, 1997), and nearly $10 \%$ of patients with BRCA1 mutations (Dong et al., 1998). Three of the four patients carrying this insertion in our sample have at least one European parent (Ukrainian/Italian, Italian, and Portuguese/German); the fourth patient did not provide any information on her ancestry. The fact that $5382 \mathrm{insC}$ occurred in unrelated patients suggests that larger-scale studies are necessary to evaluate the relevance of this mutation in Brazilian populations.

Table 2 - Mutations found in seven unrelated patients, inclusion criteria, type of cancer(s) (age at diagnosis), and number of previous reports at BIC (Breast Cancer Information Core).

\begin{tabular}{lcccc}
\hline Mutation & Inclusion criteria $^{1}$ & Type of mutation & Proband cancer (age at diagnosis) & Number of previous teports at BIC \\
\hline 5382 ins C & III and V & Frameshift & Bilateral Ovarian Cancer (45) & 536 \\
5382 ins C & II, III and V & Frameshift & Bilateral Breast Cancer (47/50) & 536 \\
5382 ins C & V & Frameshift & Bilateral Breast Cancer (47) & 536 \\
5382 ins C & V & Frameshift & Bilateral Breast Cancer (33/38) & 536 \\
Q1135X & III & Nonsense & Breast Cancer (46) & 1 \\
IVS17+2 T $>$ G & III & Splicing site & Breast Cancer (25) & 1 \\
$3450-3453$ delCAAG & II, III and V & Frameshift & Bilateral Breast Cancer (48 / 55) & 24 \\
\hline
\end{tabular}

${ }^{1}$ Some patients fitted more than one criterion. 
Although 5382insC is the most frequently reported mutation in familial breast cancer (Foulkes et al., 1999), we found it in two individuals with bilateral ovarian cancer: (i) a proband with a family history including one sister with breast cancer diagnosed at age 30 and her grandmother with a unilateral ovarian cancer diagnosed at age 60 ; and (ii) a woman with ovarian cancer diagnosed at the age of 39 years, who was related to a proband with bilateral breast cancer diagnosed at the age of 36/41 years, and with a strong family history of two other bilateral breast cancers (diagnosed at age 47/50 and 45/50, respectively,) and one unilateral breast cancer (diagnosed at age 50).

The four base-pair deletion (3450-3452delCAAG) in exon 11 was detected in a patient with bilateral breast cancer (diagnosed at age 48 and 55, respectively) and with the most impressive familial cancer history of all patients $(5$ cases of breast cancer diagnosed at ages $61,46,43,42$ and 36 , respectively, and one case of ovarian cancer diagnosed at age 44). This deletion was first described by Durocher $e t$ al. (1996) in a patient diagnosed with breast cancer at 28 years and with ovarian cancer at 34 and with a strong family history (three breast cancers diagnosed at ages 26, 29 and 40 in different relatives). As this deletion was found in different ethnic groups like African Americans (Panguluri et al., 1999) and West Europeans (Moller et al., 2002), it is likely to be of ancient origin, although haplotype analysis might be required to confirm this hypothesis.

The two other mutations found (IVS17 $+2 \mathrm{~T}>\mathrm{C}$ and Q1135X) are rare variants, previously reported only once by BIC. The patient carrying IVS17+2T $>C$, which affects a splicing site, was 47 years old at the time of diagnosis and had a family history of breast cancer in first-degree relatives: her mother, diagnosed at age 69 , and a sister at 44 . The patient with Q1135X had breast cancer diagnosed at 46 years and a family history of breast cancer including her mother, diagnosed at 38 years, and her sister, diagnosed at 40 years.

\section{Acknowledgements}

This work was supported by FAPERJ (Fundação de Amparo a Pesquisa do Estado do Rio de Janeiro), FAF (Fundação Ary Frauzino para Pesquisa e Controle do Câncer) and Ministério das Saúde, Brazil.

\section{References}

Abeliovich D, Kaduri L, Lerer I, Weinberg N, Amir G, Sagi M, Zlotogora J, Heching N and Peretz T (1997) The founder mutations $185 \mathrm{delAG}$ and 5382insC in BRCA1 and 6174delT in BRCA2 appear in $60 \%$ of ovarian cancer and $30 \%$ of early-onset breast cancer patients among Ashkenazi women. Am J Hum Genet 60:505-14.

Alves-Silva J, Santos MS, Guimarães PEM, Ferreira ACS, Bandelt HJ, Pena SDJ and Prado VF (2000) The ancestry of Brazilian mtDNA lineages. Am J Hum Genet 67:444-461.
Brose MS, Rebbeck TR, Calzone KA, Stopfer JE and Weber BL (2002) Cancer risk estimates for BRCAl mutation carriers identified in a risk evaluation program. J Natl Cancer Inst 94:1365-1372.

Brown MA, Lo LJ, Catteau A, Xu CF, Lindeman GJ, Hodgson S and Solomon E (2002) Germline BRCA1 promoter deletions in UK and Australian familial breast cancer patients: Identification of a novel deletion consistent with BRCA1: psiBRCA1 recombination. Hum Mutat 19:435-442.

Carvalho-Silva DR, Santos FR, Rocha J and Pena SDJ (2001) The phylogeography of Brazilian Y chromosome lineages. Am J of Hum Genet 678:281-286.

Corvello CM, Duarte APM, Mourão-Neto M and Simpson AJG (1998) BRCA1, BRCA2 and TP53 germline mutations in Brazilian breast cancer families. Breast Cancer Res Treat 50(Suppl):297.

Delgado LB, Gonzalez A, Fernandez G, Cataldi S, Bressac-De Paillerets B, Bombled J, Sabini G, Roca R and Muse IM (2003) BRCA1 and BRCA2 mutations in Uruguayan breast and breast/ovarian cancer families. ASCO Annual Meeting 2003, New Orleans, USA.

Dong J, Claude JC, Wu Y, Schumacher V, Debatin I, Tonin P and Pokora BR (1998) A high proportion of mutations in the BRCA1 gene in German breast/ovarian cancer families with clustering of mutations in the 3'third of the gene. Hum Genet 103:54-161.

Durocher F, Tonin P, Shattuck-Eidens D, Skolnick M, Narod SA and Simard J (1996) Mutation analysis of the BRCAl gene in 23 families with cases of cancer of the breast, ovary, and multiple other sites. J Med Genet 33:814-819

Ford D, Easton DF, Stratton M, Narod S, Goldgar D, Deville P, Bishop DT, Weber B, Lenoir G, Chang-Claude J, Sobol H, Teare MD, Struewing J, Arason A, Scherneck S, Peto J, Rebbeck TR, Tonin P, Neuhausen S, Barkardottir R, Eyfjord J, Lynch H, Ponder BA, Gayther SA and Zelada-Hedman M (1998) Genetic heterogeneity and penetrance analysis of the $B R C A 1$ and $B R C A 2$ genes in breast cancer families. The Breast Cancer Linkage Consortium. Am J Hum Genet 62:676-689.

Foulkes WD, Brunet JS, Warner E, Goodwin PJ, Meschino W, Narod SA, Goss PE and Glendon G (1999) The importance of a family history of breast cancer in predicting the presence of a $B R C A$ mutation. Am J Hum Genet 65:1776-1779.

Frank TS, Manley SA, Olopade OI, Cummings S, Garber JE, Bernhardt B, Antman K, Russo D, Wood ME, Mullineau L, Isaacs C, Peshkin B, Buys S, Venne V, Rowley PT, Loader S, Offit K, Robson M, Hampel H, Brener D, Winer EP, Clark S, Weber B, Strong LC, Rieger P, McClure M, Ward BE, Shattuck-Eidens D, Oliphant A, Skolnick MA, Thomas A (1998) Sequence analysis of BRCA1 and BRCA2: Correlation of mutations with family history and ovarian cancer risk. J Clin Oncol 16:2417-2425.

Friedman LS, Ostermeyer EA, Szabo CI, Dowd P, Lynch ED, Rowell SE and King MC (1994) Confirmation of BRCA1 by analysis of germline mutations linked to breast and ovarian cancer in ten families. Nat Genet 8:399-404.

Gao Q, Tomlinson G, Das S, Cummings S, Sveen L, Fackenthal J, Schumm P and Olopade OI (2000) Prevalence of BRCA1 and $B R C A 2$ mutations among clinic-based African American families with breast cancer. Hum Genet 107:186-91. 
Hall MJ, Lee KM, Euman B, Morrow EJ, Anderson AL, Huey B and King CM (1990) Linkage of early-onset familial breast cancer to chromossome 17q21. Science 250:1684-1689.

Hamann U, Haner M, Stosiek U, Bastert G and Scott RJ (1997) Low frequency of $B R C A 1$ germline mutations in 45 German breast/ovarian cancer families. J Med Genet 34:884-888.

Jara L, Ampuero S, Seccia L, Bustamante M, Blanco R and Ojeda JM (2002) Analysis of 5382insC (BRCA1) and 6174delT (BRCA2) mutations in 382 healthy Chilean women with a family history of breast cancer. Biol Res 35:85-93.

Kasprazak L, Foulkes WD and Shelling AN (1999) Hereditary ovarian carcinoma. BMJ 318:786-789.

Kinney AY, Croyle RT, Dudley WN, Bailey CA, Pelias MK and Neuhausen SL (2001) Knowledge, attitudes, and interest in breast-ovarian cancer gene testing: A survey of a large African-American kindred with a BRCA1 mutation. Prev Med $33: 43-51$

Langston AA, Malone KE, Thompson JD, Daling JR and Ostrander EA (1996) BRCA1 mutations in a populationbased sample of young women with breast cancer. N Engl J Med 334:137-142.

Loman N, Johannsson O, Kristoffersson U, Olsson H and Borg A (2001) Family history of breast and ovarian cancers and $B R C A 1$ and $B R C A 2$ mutations in a population-based series of early-onset breast cancer. J Natl Cancer Inst 93:1215-23.

Los Rios P, Jack E, Kuperstein G, Lynch E, Lubinsky J and Narod AS (2001) Founder mutations of BRCA1 and BRCA2 in North American families of Polish origin that are affected with breast cancer. Am J Hum Genet 68:546-450.

Martin AM, Blackwood MA, Antin-Ozerkis D, Shih HA, Calzone K, Colligon TA, Seal S, Collins N, Stratton MR, Weber BL and Nathanson KL (2001) Germline mutations in BRCA1 and $B R C A 2$ in breast-ovarian families from a breast cancer risk evaluation clinic. J Clin Oncol 19:2247-53.

Miki Y, Swensen J, Shattuck-Eidens D, Futreal PA, Harshman K, Tavtigian S, Liu Q, Cochran C, Bennett LM, Ding W, Bell R, Rosenthal J, Hussey C, Tran T, McClure M, Frye C, Hattier T, Phelps R, Strano HA, Katcher H, Yakumo K, Gholami Z, Shaffer RD, Stone S, Bayer S, Wray C, Bogden R, Ward J, Narod S, Bristow KP, Helvering R, Morrison P, Rosteck P, Lai M, Lewis C, Neuhausen S, Albright CR, Wiseman R, Kamb A and Skolnick M (1994) A strong candidate for the breast and ovarian cancer susceptibility gene BRCA1. Science 266:66-71.

Miller SA, Dykes DD and Polesky HF (1988) A simple salting procedure for extracting DNA from human nucleated cells. Nucleic Acid Res 16:215.

Moller P, Borg A, Evans DG, Haites N, Reis MM, Vasen H, Anderson E, Steel CM, Apold J, Goudie D, Howell A, Lalloo F, Maehle L, Gregory H and Heimdal K (2002) Survival in prospectively ascertained familial breast cancer: Analysis of a series stratified by tumour characteristics, $B R C A$ mutations and oophorectomy. Int J Cancer 101:555-559.

Montagna M, Palma MD, Menin C, Agata S, De Nicolo A, Chieco-Bianchi L and D'Andrea E (2003) Genomic rearrangements account for more than one-third of the BRCA1 mutations in northern Italian breast/ovarian cancer families. Hum Mol Genet 12:1055-61.

Offit K (1998) Clinical Cancer Genetics - Risk, Counseling and Management. Willey Liss, New York, 419 pp.
Olopade OI, Fackenthal JD, Dunston G, Tainsky MA, Collins F and Whitfield-Broome C (2003) Breast cancer genetics in African-Americans. Cancer 97(Suppl. 1):236-45.

Panguluri RC, Brody LC, Modali R, Utley K, Adams-Campbell L, Day AA, Whitfield-Broome C and Dunston GM (1999) $B R C A 1$ mutations in African Americans. Hum Genet 105:28-31.

Rohlfs EM, Puget N, Graham ML, Weber BL, Garber JE, Skrzynia C, Halperin JL, Lenoir GM, Silverman LM and Mazoyer S (2000) ALU-mediated 7,1kb deletion of BRCA1 exons 8 and 9 in breast and ovarian cancer families that results in alternative splicing of exon 10. Genes Chromosomes Cancer 28:300-307.

Ruiz-Flores P, Sinilnikova OM, Badzioch M, CalderonGarciduenas AL, Chopin S, Fabrice O, Gonzalez-Guerrero JF, Szabo C, Lenoir G, Goldgar DE and Barrera-Saldana HA (2002) BRCA1 and BRCA2 mutation analysis of early-onset and familial breast cancer cases in Mexico. Hum Mutat 20:474-5.

Shattuck-Eidens D, Oliphant A, McClure M, McBride C, Gupte J, Rubano T, Pruss D, Tavtigian SV, Teng DH, Adey N, Staebell M, Gumpper K, Lundstrom R, Hulick M, Kelly M, Holmen J, Lingenfelter B, Manley S, Fujimura F, Luce M, Ward B, Cannon-Albright L, Steele L, Offit K, Gilewski T, Norton L, Brown K, Schulz C, Hampel H, Schluger A, Giulotto E, Zoli W, Ravaioli A, Nevanlinna H, Pyrhonen S, Rowley P, Loader S, Osborne MP, Daly M, Tepler I, Weinstein PL, Scalia J, Michaelson R, Scott RJ, Radice P, Pierotti MA, Garber JE, Isaacs C, Peshkin B, Lippman ME, Dosik MH, Caligo M, Grenstein RM, Pilarski R, Weber B, Burgemeister R, Frank TS, Skolnick MH and Thomas A (1997) BRCA1 sequence analysis in women at high risk for susceptibility mutations. Risk factor analysis and implications for genetic testing. JAMA 278:1242-1250.

Shen D, Wu Y, Subbarao M, Bhat H, Chillar R and Vadgama JV (2000) Mutation analysis of BRCA1 gene in AfricanAmerican patients with breast cancer. J Natl Med Assoc 92:29-35.

Simard J, Tonin P, Durocher F, Morgan K, Rommens J, Gingras S, Samson C, Leblanc JF, Belanger C, Dion F, Liu Q, Skolnick M, Goldgar D, Shattuck-Eidens D, Labrie F and Narod S (1994) Common origin of BRCA1 mutation in Canadian breast and ovarian cancer families. Nat Genet 8:392398.

Simon SD, Molina A and Moreira-Filho CA (2003) Mutations of $B R C A 1 / 2$ genes in Brazil. ASCO Annual Meeting 2003, New Orleans, USA.

Szabo CI and King MC (1997) Population genetics of BRCA1 and BRCA2. Am J Hum Genet 60:1013-20.

Trincado P, Fardella C, Mayerson D, Montero L, O'Brien A, Barrueto K and Gallegos R (1999) Prevalence of the 185Ag deletion of the BRCA1 gene in Chilean women with breast neoplasm. Rev Med Chil 127:19-22.

Unger MA, Nathanson KL, Calzone K, Antin-Ozerkis D, Shih HÁ, Martin AM, Lenoir GM, Mazoyer S and Weber BL (2000) Screening for genomic rearragements in families with breast and ovarian cancer identifies BRCAl mutation previously missed by conformation-sensitive gel electrophoresis or sequencing. Am J Hum Genet 67:841-850.

Associate Editor: Emmanuel Dias Neto 